\title{
DISCIPLINARY CRISIS IN VALORISATION OF ART
}

Generally speaking, values among objects - as well as among art valuables - are defined based on the especially significant properties and qualificatives differentiating i.e. privileging that artwork within a family of congenial phenomena/objects; first in the time of its origination and then in present time. The history of aesthetics and that of cultures both mirror the unstable status of the qualificatives of art value i.e. conditions for the historical transformations of valorisation. Objects or phenomena which pretended to be what we today call the valuable artworks, have acquired the required qualification within a hierarchised framework of their own time's cultural demand ${ }^{1}$. A dynamic system of changes in equalising artwork's value with its social status brought about the disciplinary crisis of art theory, which failed to adapt axiologically to the new receptions of art and the standards of actual time. ${ }^{2}$ I'll derive a short account of crisis from the fundamental questions concerning the meaning of beauty, value and valorisation within culture and art, through history. The crisis arises during the period from the sixteenth to the eighteenth century, when art history became disciplinary articulated, incorporating the valorisation mechanisms of that time into its own methodological matrix, as if it was supratemporal and 
Homer and Phidias are still beautiful, while the good and the true of their time are no longer in all respects ours.

Jacob Burckhardt

\section{HISTORICAL CRYPTOGRAMS OF VALUES}

Let's take the example of the archaic smile from the mythological culture of pre-Socrates era, a famous smile of Kouros of Tenea. By the fifth century $\mathrm{BC}$, this smile disappeared from the faces of Polycleitus' figures, vanishing without a trace to a degree that if Polycleitus' Doryphoros were to feature such a smile, he would look so transformed that we'd seek analytical approaches other than those already known and standardised. In time, step by step, the ideal ratio was changing and body got elongated. Hence Praxiteles' Hermes or Lysippus' Apoxyomenos appear almost feminine, though literature gladly diverts our gaze from stature to counterpoise. Phidias' statue of god Ilissos, although squeezed into a corner of Parthenon's pediment abolishes - in quite a revolutionary manner - the importance of the passive authority of youngster present in his predecessor's works. However, all these artworks are valuables. Many important items have been lost, but nevertheless remained connected with the so called antique ideal of beauty, manifested in ratio between parts, to the advantage of a very stretchable notion of realism.

Centuries later, as the classicism of post-Baroque and Enlightenment got connected with the unclear formula of antique paragon, we were left with an open question: besides the so called realistic beauty of ratio, which properties of the values are we referring to? The change of historical context deprived many unimportant items of its meaning. Neo-classicist ideal was based on Roman monumentality rather than on Greek distancing. Therefore, yet another importance was maximally reduced to the advantage of a totally different importance, despite an apparent similarity of their forms. Namely, the formal concept of Classicism rests on a monumental gesture and decoration which, in the European historic circumstances of the time, should be comprehended as the valuable surpassing of antique paragon style description. Wedged in between Antiquity and Classicism, before Renaissance, lay the ten centuries of total transformation of all the previous important items pertaining to understanding artwork's value. Image became language. And language was an encrypted concept. To put it better, it was a case of conspiracy between the opposed Medieval languages, who've been reconciling their mutual misunderstanding by sharing the same aim - a path to God. Deciphering the western Christian symbolism, one could claim that a path to God was dedication in faith which often, from the iconographical aspect, was symbolised by a shackled, tailless, 
humanoid monkey. ${ }^{3}$ In Christian art, the figure of monkey is used as a denotation of sin, malice, slyness and lust. Sometimes it denotes a wicked human soul, blinded and sinful, hence Satan is frequently depicted in a monkey's shape. ${ }^{4}$

Accordantly, small Dürer's print - from the artist's rich heritage featuring the motif of Madonna ${ }^{5}$ - has been similarly described in art history and often misinterpreted. I am not aware of a single case where it was referred to correctly. Obviously, the monkey depicted in the painting's lower left corner possesses status and meaning entirely differing from the usual ones. It is unquestionable that, in regard to its art status, the print is a historic valuable. However, its history is discerned from graspable facts which are incompletely systemised. For instance, there is always a consensus regarding this artwork's formal description, present influence of Italian iconography, a mode of using attributes, the introduction of local landscape and contemporary details (e.g. Madonna's dress), a head outside aureole's centre etc. There are even detailed analyses of Dürer's inclination towards painting Madonna, written as psycho-biographic essays with psychoanalytical pretensions. Still, two unusual issues are perceived in all these cases. First, the painting cannot be called Virgin and Child with the Monkey if the title is aspiring to the credibility of iconological analyses which tackle it. Namely, next to Virgin's leg sits a shackled, chained monkey. This is simply the heritage of classical Christian iconographic repertoire, where the chained monkey unambiguously symbolises sin overpowered by faith. If the monkey was sitting next to her leg (as written in all the motif's names), in this sacred scene Virgin would be accompanied by sin, lust and perhaps even Satan. It remains unclear whether Dürer was so subversive to title his artwork Virgin and Child with the Monkey or whether, naming this piece on their own, Dürer's interpreters displaced an important detail outside the analysis' focus.

Secondly, the painting possesses no direct function of piety. Dürer was both prolific painter and writer and, year before his demise, largely inspired by Luther's Reformation ideas noted the following: "There is no idolatry in the arts unless someone deliberately introduces it. Moreover, I believe that no one would be so nonsensical as to address his prayers to wood, stone, metal or paints."

As we see, the collection of descriptions attributed to an artwork, or the history of value, frequently differs from what the author originally encrypted in his or her artwork. Instead of an authentic history of value or a document of past time, we are left with exploring its further historicity, continuity in transitoriness, along with recollection and observation, which includes the always new revisions of old descriptions. ${ }^{\text {? }}$ 
Inasmuch, I believe that promoting a postmodernist idea of post-historical time actually constitutes a case of reacting to the institutional stabilisation of the totally unstable aspects of historical valorisation. Therefore, this is not about the decentring from a historical position - a quite impossible feat, anyway. History demonstrated through the institutions of state, church and institutionalised culture acquires the untouchable status of grave, instead of self-aware recollection within the living life's contexts. Moreover - through law and religion - it ensures protection from the vandalism and sacrilege of subsequent opening i.e. discussion. Rather than desecrating the grave, we're left with a possibility of conceptual polemics over its monumental value, just as in the artwork by Braco Dimitrijević which primarily tackles the monumental, untouchable status of history, as the exhibited marble obelisk says: "There are no mistakes in history. The whole of history is a mistake." ${ }^{\prime 8}$ On the other hand, such artwork, when submitted to analysis as taught by the art history's methodology, leaves us with the impenetrable fact of value, with very little meaning and importance.

\section{FORMULA OF THE BEAUTY OF THE MOMENT}

In accord with their epoch's sudden scientification - in yet non-dissociated relations with the heritage of the Middle Ages - Renaissance writers, many of them artists themselves (painters, sculptors or architects) have found that the idea of beauty ${ }^{9}$ links science, genius' divine talent and the predominance of Christian narrative in iconography. They considered beauty to be immanent to objects, expressible only by genius and recognisable only through good taste (a class dogma of the time). Beauty became the central qualificative in valorising Early Modern Period art, with Beux art remaining a part of some academies' titles to this day. The sixteenth century valorisers of art included Giorgio Vasari. In the spirit of paying homage to the criteria of beauty, he saw medieval art as rigid and much less beautiful than "the triumph of beauty and grace" 10 in the works of his fellow citizens and contemporaries.

In the 1850s, two hundred years after Vasari, Winckelman entirely reduced historically conditioned, complex antique qualificatives to the notion of style which progresses or regresses on a single, fragile thread pertaining to a notion of the predominance of exalted beauty's qualificatives ${ }^{11}$. He is also considered to be one of the fathers of art history as discipline, if Vasari was grandfather of that same tribe. Only two years later, his close collaborator Lessing, in a famous discussion on Hellenistic sculpture Laocoon with his Sons ${ }^{12}$, explicitly rejects a characteristic of temporality in visual arts, since the latter represent and visually portray an arrested moment. It is along the lines of this famous reduction that many schools to this day use a restrictive notion of plastic instead of visual arts in their curriculums. 
With Neoclassicism, the targeted paragon of form was its own peculiar, utilitarian pathos of its own frozen and great present. The neo-classicist eighteenth century elaborated Vasari's formula which imposed the standard of beauty as an instrument of representation and advocating various ideals. From a disciplinary point, such standard could be applied to judging values from the entire previous history, aiming at general valorisation and future application. Thus, the beauty standard functioned through the various types of realism, because the beauty qualificative could be interpreted through differing historical paradigms.

A problem emerged when, simultaneously with the birth of art history as we know it, a range of other qualificatives was imposed, in a manner that the idea of beauty as a representative of historical ideals begun loosing much of its importance and historical glow.

The new qualificatives of the simultaneous appearance of early Romanticism didn't adhere to the old and rather rigid standards. Already by the 1850 s, John Ruskin had to seek valid arguments in defending Turner's work ${ }^{13}$. The face of beauty begun mirroring the interior of the world of objects and contents of experiencing the world, instead of the world itself. However, art history wasn't much confused by this change, as witnessed by the further, in my opinion, failed application of old style qualificatives to new art e.g. Gericault's or Delacroix's works. These individuals' activism and explicit critique of government was shadowed by one of the most incomprehensible style variants, called Romanticism. It was Baudelaire who clearly articulated that Romanticism is not about style, albeit about a mode of feeling. This shift from the universalising style paradigm towards the subject's individual emotion actually opened the doors to Modernism $^{14}$. Within academic, state-making circles the style doctrine (a term denoting little more than a fad) crumbled into dry academicism, defending an alliance between preference and norm as the only pass to the world of values.

Unfortunately, art history begun its independent life with this reduction of early historical importance. To this day, a description of values as the valorising argument - established by Vasari - became not so much explicit as it became relevant. A perspective, i.e. illusion of space is based on the comparative method and the definition of progress, along the postulates of virtual realism, the latter being identified with beauty. Today's theoretical analyses of Vasari's approach - suggesting that the writer's inclination to simulating the illusion of reality succumbed, both pragmatically and in the spirit of times, to the tendency of instrumentalising observer ${ }^{15}$ - seem to have remained on some parallel world's plateau. 


\section{CULTURAL FUNCTION OF ARTWORK}

Equally neglected is the contribution of art theory, which turned towards the new reception of old paintings. The comprehensive and layered $10^{\text {th }}$ footnote in Walter Benjamin's essay is dedicated to Raphael's Sistine Madonna ${ }^{16}$. Here Benjamin doesn't enter formal artwork's analysis but tackles a relation between the painting's two different and contradictory value statuses: one emerging from its exhibitory function, and the other which degrades it in further cultural context. The artwork's properties of value, says Benjamin, can be comprehended exclusively within its historical context. Building his question from a fact that a masterpiece ended up on an altar of a provincial church in Piacenza, Benjamin asks why the reception of artworks proceeds with differing accents, of which two polarised ones stand out. One of these accents concerns the cultural value while the other pertains to the exhibitory value. Transition from the first kind of art reception to another is defined by the general historical flux of art reception. Regardless, one could prove that - in principle - each particular artwork is vacillating between these two polarised kinds of reception. In this context, Sistine Madonna was exhibited on the occasion of the first public laying out of Sixtus on a catafalque in the lateral St. Peter's chapel, where it was placed in the niche's back. The aim was to conjure how Madonna, passing through open green curtains, approaches pope's coffin. Thus, says Benjamin, Raphael's painting found its extraordinary exhibitory purpose within a funeral festivity. Later on it was relocated at the main altar of provincial Black Friars' monastery church in Piacenza. This compromise exile was due to a fact that Roman ritual forbids paintings exhibited at funeral festivities to be used for the purpose of cult at the main altar. Despite these regulations, Raphael's work - owing to its special beauty praised by contemporaries - eventually got installed at the main altar, albeit in a province, to avoid scandal in Curia. The painting's cultural value devalued the exhibitory one, concludes Benjamin.

Therefore, critical theory turned towards the theme of artwork's cultural function in relation to the types of its exposure and regarding the problem of media function - a logical consequence of technological progress in the late nineteenth and early twentieth century. Ignoring the importance of artwork as a historical medium became a crucial valorisation issue only after the 1950 s.

Besides transforming the historical values, weakness in art valorisation is present in self-valorisation or self-importance of states and religions, and consequently of the state-making cultural institutions which immeasurably influenced the nature of the accepted forms of valorisation, including the development of art history as we know it. Many of the related cases are well known, at least in 
their radical historical manifestations. Burckhardt describes them in following words: "(This) tremendous force, adhered by everything it comes across, consequently becomes a power." 17

Description, analysis and interpretations of works done after the rise of Romanticism were not applicable anymore, since they were executed by instruments applied to art preceding the late eighteenth century. The old forms of valorisation were denied by the new importance which entered the world of values through another door. As a consequence of the staunch institutional application of old importance to the emergence of new values, recipients lost the confidence in the unquestionable statues of value, in a wider sense. And art, losing social communication, retreated to the small stationeries of monodisciplinary worlds.

At a certain moment, a changed concept of importance in modern era sought the right to change the status of value, while epoch's normativeness couldn't accept the loss of control and the breakdown of systematised omniscience's spiritual coliseum. The epoch didn't want to succumb to an onslaught of the unnormed manners of artistic expression. Therefore valorisation became enclosed within the special classes of mutually alienated valuators.

Avoiding the premature dream of desirable transdisciplinarity, instead of disciplinary interpenetration we are still deep in monodisciplinarity, which is filled with specialised niches or - at best - tolerant to multidisciplinarity.

Therefore - to this very day - when analysing the historical heritage of art values we insist on the ideology of division along the style periods instead of historical eras, thus depriving history of its right to historicity. The causes for this lay within the educational system, one based on studying artworks dating mainly from older eras and exhausting itself through theoretical literature dealing principally with older epochs. By saying this I am, by no means, advocating bringing the old specimens to foreground, but suggesting a methodological openness towards a permanent revision of their importance outdated interpretations, as well as towards the permanent critique of new values, regardless the power and functions of their institutional aegis. Thus, the valuator finally arrives at the centre of the question of potential connecting the values and valorisation, as the mover of lever we are still referring to as Humanities. 

some piece is an artwork i.e. rendering the art status, is happening dependant on "institutional status" of the name giver. Cf. George Dickie, "Defining Art," The American Philosophical Quarterly, no. 6 (1969): 253-256.

Hans Belting radically articulated crisis as "the end of the history of art". (Cf. Hans Belting, "The End of the History of Art?" History and Theory, no. 27 (1988): 188-199.) Besides, contemporary theory speaks of active reception surpassing arbitrage of any kind of mono-disciplinary viewpoint on art (Term "active reception" taken from: Marita Struken and Lisa Cartwrigt, Practices of Looking (New York: Oxford University Press, 2001)).

Referring to the encrypted concept of symbolic Medieval language,substantially incorporated into the painting vocabulary of Renaissance to a considerable degree.

Anđelko Badurina, Leksikon ikonografije, liturgike i simbolike zapadnog kršćanstva. (Zagreb: Sveučilišna naklada Liber, Kršćanska sadašnjost, Institut za povijest umjetnosti, 1979): 391. 
Acc. to: Angela Hass. „Albrecht Dürer's devotional images of the Virgin and child.“ Accessed June 27, 2017. https://www.ngv.vic.gov.au/essay/albrecht-durers-devotional images-of-the-virginand-child/.

If for no other reason, then because of the symbolic function of valorisation of art, tackled by Nelson Goodman in his Ways of Worldmaking. Such function of valorising results in historically and culturally unstable symbolization, hence an artwork's status succumbs to the effect of "transitoriness", constantly demanding new revisions from a position of contemporary recipient.

Or, as formulated by Nicolas Bourriaud in a letter sent to Braco Dimitrijević on a subject of meaning and sense of post-historical position of art: But when you talk about a "post" state of History, it has nothing to do with its end. (Cf. Nicolas Bourriaud, "Letter to Braco Dimitrijević about posthistory." Accessed Aug 17, 2017. http://bracodimitrijevic.com/index.php?p=pages\&title=Essayson-B.-D.-Work.)

The idea has been developed since antiquity, yet with essential changes. Plato refers to it as intellectual, Plotinus as spiritual, while Thomas of Aquinas calls it divine. Although in all the cases it remains a cognitive category. It was the Renaissance pattern that ascribed beauty with the high and idealized importance of mundane embodiment, to the disadvantage of realism.

Reference to the content of the $3^{\text {rd }}$ part of Giorgio Vasari, The Lives of the Artists (New York: Oxford University Press, 2008).

Cf. Johann Joachim Winckelmann, "Essay on the Beautiful in Art," in Winckelmann's Writings on Art, edited by David Irwin (London: Phaidon, 1972), 89-104.

Gotthold Ephraim Lessing, Laokoon ili O granicama slikarstva i poezije (Beograd: Kultura, 1954).

Ruskin writes extensively on Turner in the first and second volume of Modern Painters. Cf. John Ruskin, Modern Painters (Adamant Media Corporation, 2000).

Cf. Charles Baudelaire, "The Salon of 1846," in Romanticism. Selected documents, edited by John B. Halsted (London: Macmillan \& Co LTD, 1969), 118-122.

Cf. Svetlana Alpers Leontief, "Ekphrasis and Aesthetic Attitudes in Vasari's Lives," Journal of the Warburg and Courtauld Institutes, no. 23 (2/4, July - December 1960): 190-215.

Cf. Walter Benjamin, "Umjetničko djelo u doba svoje tehničke reproduktivnosti," Život umjetnosti : časopis za suvremena likovna zbivanja, no. 6 (1968): 71. 
Alpers, Leontief Svetlana. "Ekphrasis and Aesthetic Attitudes in Vasari's Lives." Journal of the Warburg and Courtauld Institutes, no. 23 (2/4, July - December 1960): 190-215.

Badurina, Anđelko. Leksikon ikonografije, liturgike i simbolike zapadnog kršćanstva. Zagreb: Sveučilišna naklada Liber, Kršćanska sadašnjost, Institut za povijest umjetnosti, 1979.

Baudelaire, Charles. "The Salon of 1846." In Romanticism. Selected documents, edited by John B. Halsted, 118-122. London: Macmillan \& Co LTD, 1969.

Belting, Hans. "The End of the History of Art?" In History and Theory, no. 27 (2, 1988): 188-199.

Benjamin, Walter. "Umjetničko djelo u doba svoje tehničke reproduktivnosti." In Život umjetnosti : časopis za suvremena likovna zbivanja, no. 6 (1968): 67-80.

Bourriaud, Nicolas. "Letter to Braco Dimitrijević about post-history.” Accessced Aug 17, 2017. http://bracodimitrijevic.com/index.php? $\mathrm{p}=$ pages\&title=Essays-on-B.-D.-Work.

Burckhardt, Jacob. Razmišljanja o svjetskoj povijesti. Zagreb: Prosvjeta, 1999.

Dickie, G. "Defining Art.” The American Philosophical Quarterly, 6 (3) (1969): 253-256.

Goodman, Nelson. Ways of Worldmaking. Indianapolis: Hackett Publishing Company, 1978.

Hass, Angela. "Albrecht Dürer's devotional images of the Virgin and child.” Accessced June 27, 2017. https://www.ngv.vic.gov.au/essay/albrecht-durers-devotional images-of-the-virgin-andchild/.

Lessing, Gotthold Ephraim. Laokoon ili O granicama slikarstva i poezije. Beograd: Kultura, 1954.

Ruskin, John. Modern Painters. Adamant Media Corporation, 2000.

Struken, Marita and Cartwrigt, Lisa. Practices of Looking. New York: Oxford University Press, 2001.

Vasari, Giorgio. The Lives of the Artists. New York: Oxford University Press, 2008.

Winckelmann, Johann Joachim. "Essay on the Beautiful in Art." In Winckelmann's Writings on Art, edited by David Irwin, 89-104. London: Phaidon, 1972. 


\section{SAVREMENI ESTETIČAR KAO TERAPEUT NESRAZMERE MEĐU ČULIMA Dragan Prole}

Prvo deo članka izlaže pozadinu i motivaciju Makluanovog pojma otuđenja kao posledicu moderne vizuelne kulture. Budući da je ta kultura prevashodno proizvedena posredstvom tradicionalnih medija, a ne putem ekonomskih organizacija, uvid u strukturu medija otkriva postojanje izvesne nesrazmere među čulima. Imajući u vidu da je za tu nesrazmeru odgovoran linearni svet pisma, autor analizira Makluanovu sugestiju da okret prema novim elektronskim medijima implicira savremene promene u kojima će novi mediji destruirati staro sopstvo. Nakon razmatranja razloga za krajnje optimistična očekivanja od novih audio-vizuelnih medija u pružanju podrške za uspostavljanje izvornog, balansiranog i uravnoteženog čoveka, autor razmatra održivost ideje o stvaranju nove medijske samosvesti zahvaljujući doprinosima studiranja novih pristupa različitim modelima čulnosti. U zaključku autor naglašava da estetičar onda nije ekspert za umetničku transcendenciju, nego terapeut ugrožene ravnoteže među čulima.

KLJUČNE REČI: MAKLUAN, AVANGARDE, OTUĐENJE, ČULNA SRAZMERA, CELOKUPNI ČOVEK

\section{DISCIPLINSKA KRIZA U VREDNOVANJU UMETNOSTI \\ Nataša Lah}

Uopšteno govoreći, vrednost među objektima - kao i među umetničkim vrednostima - definišu se na osnovu posebno značajnih odlika i uslova koji razlikuju npr. privilegovanje tog umetničkog dela u okviru porodice srodnih pojava i predmeta; prvo u vreme nastanka, a onda i u sadašnjem vremenu. Istorija estetike i kulture odražavaju nestabilan status uslova koji određuju umetničke vrednosti, tj. uslova za istorijsku promenu vrednovanja. Predmeti ili pojave koji tokom istorije pretenduju da budu ono što danas nazivamo vrednim umetničkim delima, stekli su neophodne kvalifikacije u okviru hijerarhijskog okvira kulturne potražnje njihovog vremena. Dinamičan sistem promena ujednačavanja vrednosti umetničkih dela sa njihovim društvenim statusom doveo je do disciplinarne krize teorije umetnosti koja nije uspela da se prilagodi aksiološki novim načinima prijema umetnosti, ni savremenim standardima. U tom smislu, daću kratak prikaz krize sa stanovišta osnovnih pitanja u vezi značenja lepote, vrednosti i vrednovanja u okviru kulture i umetnosti tokom istorije. Lociraću fokus ove krize u okviru perioda od šesnaestog do osamnaestog veka (bez romantizma) kada je istorija umetnosti postala jasno izražena disciplina, uključujući mehanizme vrednovanja tog perioda u svoju posebnu metodološku matricu, kao da je ona vanvremenska i neistorijska.

KLJUČNE REČI: AKSIOLOGIJA UMETNOSTI, ISTORIJSKE PARADIGME VREDNOVANJA, AKSIOLOŠKA MATRICA ISTORIJE UMETNOSTI, KULTURNO PRIHVATANJE VREDNOSTI

POSTMODERNIZAM I POST-SOCIJALISTIČKI USLOV:

15 GODINA KASNIJE (2003-2018)

\section{Aleš Erjavec}

Autor daje kratak rezime koncepta ,post-socijalističkog“ili avangardnog pokreta „,treće generacije“. On objašnjava istorijske i političke uslove koji su omogućili pojavljivanje ove specifične avangardne umetnosti. Po njegovom mišljenju, jedinstvena vrsta umetnosti se pojavila u socijalističkim zemljama tokom raspada socijalizma sovjetskog tipa usled sličnih okolnosti. Kada su se globalni i lokalni politički uslovi promenili, ova umetnost je uglavnom nestala, ostavljajući za sobom samo tragove svog postojanja. Autor ističe specifične likovne mehanizme korišćene u ovakvoj umetnosti i tvrdi da je treba priznati kao još jednu vrstu avangardne umetnosti dvadesetog veka. 